\title{
Beneficial Effects of Exogenous Melatonin and Dopamine on Low Nitrate Stress in Malus hupehensis
}

\author{
Peihua Du, Baoying Yin, Yang Cao, Ruoxuan Han, Jiahao Ji, Xiaolong He, Bowen Liang* \\ and Jizhong $X u$
}

College of Horticulture, Hebei Agricultural University, Baoding, China

OPEN ACCESS

Edited by:

Ping Wang,

lowa State University, United States

Reviewed by:

Dong Liang,

Sichuan Agricultural University, China

Piyush Mathur,

University of North Bengal, India

Kiran Bamel,

University of Delhi, India

*Correspondence:

Bowen Liang

Ibwnwsuaf@126.com;

Ibw@hebau.edu.cn

Specialty section:

This article was submitted to

Plant Abiotic Stress,

a section of the journal

Frontiers in Plant Science

Received: 02 November 2021

Accepted: 20 December 2021

Published: 28 January 2022

Citation:

Du P, Yin B, Cao Y, Han R, Ji J,

He X, Liang B and Xu J (2022)

Beneficial Effects of Exogenous

Melatonin and Dopamine on Low

Nitrate Stress in Malus hupehensis.

Front. Plant Sci. 12:807472.

doi: 10.3389/fp/s.2021.807472
Malus hupehensis, as an apple rootstock, is an economically important tree species popular due to its excellent fruit yield and stress resistance. Nitrogen is one of the critical limiting factors of plant growth and fruit yield, so it is crucial to explore new methods to improve nitrogen use efficiency. Melatonin and dopamine, as multifunctional metabolites, play numerous physiological roles in plants. We analyzed the effects of exogenous melatonin and dopamine treatments on the growth, root system architecture, nitrogen absorption, and metabolism of $M$. hupehensis when seedlings were exposed to nitratedeficient conditions. Under low nitrate stress, plant growth slowed, and chlorophyll contents and ${ }^{15} \mathrm{NO}_{3}{ }^{-}$accumulation decreased significantly. However, the application of $0.1 \mu \mathrm{mol} / \mathrm{L}$ melatonin or $100 \mu \mathrm{mol} / \mathrm{L}$ exogenous dopamine significantly reduced the inhibition attributable to low nitrate levels during the ensuing period of stress treatment, and the effect of dopamine was more obvious. In addition to modifying the root system architecture of nitrate-deficient plants, exogenous melatonin and dopamine also changed the uptake, transport, and distribution of ${ }^{15} \mathrm{NO}_{3}{ }^{-}$. Furthermore, both exogenous melatonin and dopamine enhanced tolerance to low nitrate stress by maintaining the activity of enzymes (NR, NiR, GS, Fd-GOGAT, and NADH-GOGAT) and the transcription levels of related genes involved in leaf and root nitrogen metabolism. We also found that exogenous melatonin and dopamine promoted the expression of nitrate transporter genes (NRT1.1, NRT2.4, NRT2.5, and NRT2.7) in nitrate-deficient plant leaves and roots. Our results suggest that both exogenous melatonin and dopamine can mitigate low nitrate stress by changing the root system architecture, promoting the absorption of nitrate, and regulating the expression of genes related to nitrogen transport and metabolism. However, according to a comprehensive analysis of the results, exogenous dopamine plays a more significant role than melatonin in improving plant nitrogen use efficiency.

Keywords: nitrate deficiency, melatonin, dopamine, nitrate uptake, Malus hupehensis

\section{INTRODUCTION}

Nitrogen $(\mathrm{N})$ is required in large amounts by plants, and plant growth and productivity can be restricted when it is deficient (Maathuis, 2009; Liu et al., 2021). However, soils frequently fail to provide sufficient levels of $\mathrm{N}$ to sustain optimal plant growth and development (Jia et al., 2019). The application of $\mathrm{N}$ fertilizer has contributed greatly to crop yields, largely alleviating the pressure 
caused by the global population surge. Nevertheless, there is evidence that crops use only $30-50 \%$ of the $\mathrm{N}$ applied, and the loss of reactive $\mathrm{N}$ from agricultural soils causes serious environment pollution (Guo et al., 2010; Su et al., 2020). Thus, it is necessary to enhance crop nitrogen use efficiency (NUE) to improve yield quality with low $\mathrm{N}$ investment (Liu et al., 2021).

Nitrate $\left(\mathrm{NO}_{3}{ }^{-}\right)$is one of the two major forms of inorganic $\mathrm{N}$ absorbed from the soil by plants. Under aerobic conditions, $\mathrm{NO}_{3}{ }^{-}$is the predominant form of $\mathrm{N}$ (Wang Y. Y. et al., 2018). $\mathrm{NO}_{3}{ }^{-}$is principally absorbed into roots through $\mathrm{NO}_{3}{ }^{-}$ transporters from the nitrate transporter (NRT) families (Kiba et al., 2012; Lezhneva et al., 2014). During the assimilation process for conversion into amino acids, $\mathrm{NO}_{3}{ }^{-}$is first reduced and transformed into nitrite $\left(\mathrm{NO}_{2}{ }^{-}\right)$by nitrate reductase (NR) in the cell cytosol and then reduced and transformed into ammonium $\left(\mathrm{NH}_{4}{ }^{+}\right)$by nitrite reductase $(\mathrm{NiR})$ in chloroplasts or plastids (Xu et al., 2012). Subsequently, $\mathrm{NH}_{4}{ }^{+}$is assimilated to glutamine and glutamate by glutamine synthetase (GS) and glutamate synthase (GOGAT), respectively (Huang et al., 2018). $\mathrm{NO}_{3}{ }^{-}$can be stored in large quantities in plant vacuoles and recovered as needed; however, the $\mathrm{NO}_{3}{ }^{-}$content available from soil fluctuates sharply over short distances and periods (Jia et al., 2019). Therefore, to determine the ratio among assimilation, tissue distribution, and vacuolar storage after $\mathrm{NO}_{3}{ }^{-}$absorption by plants from roots to optimize access to $\mathrm{NO}_{3}{ }^{-}$under limiting conditions, plants must first establish mechanisms to monitor external $\mathrm{NO}_{3}{ }^{-}$ supply levels efficiently, then respond to $\mathrm{N}$ demand from the various plant tissues, and eventually systematically transmit this information to activate metabolic enzymes and transporters via transcription or posttranscriptional regulation (Wang Y. Y. et al., 2018).

Melatonin ( $N$-acetyl-5-methoxytryptamine) is a pleiotropic molecule with many diverse functions in plants (Arnao and Hernandez-Ruiz, 2019). After it was first identified in vascular plants (Dubbels et al., 1995; Hattori et al., 1995), numerous studies revealed that it is a general antioxidant compound capable of interacting with huge amounts of reactive oxygen species (ROS) and reactive nitrogen species (RNS), making it a significant factor in the stability of biological membranes, particularly mitochondrial membranes (Wang et al., 2017). Plant melatonin not only takes on an antioxidative role to remove ROS, but also exerts substantial effects in many physiological processes, such as seed germination, growth, flowering, and protection against biotic and/or abiotic stressors (Arnao and Hernandez-Ruiz, 2019; Liang et al., 2019). Recently, the identification of the first plant melatonin receptor in Arabidopsis thaliana led to consideration of this regulatory molecule as a new plant hormone (Wei et al., 2018).

Dopamine (3-hydroxytyramine or 3,4dihydroxyphenethylamine) is a catecholamine, which are widespread in both animals and plants. It is a neurotransmitter in mammals that has been implicated in processes such as reward, addiction, and hormonal secretion (Wang S. et al., 2018). Since dopamine was first discovered in plants (Kimura, 1968), several studies have uncovered its important role in plants. However, in contrast to the huge amount of knowledge about its functions in mammals, the physiological significance of dopamine in plants remains unclear. Tyramine and L-dopa, the precursors of dopamine, are generated via either tyrosine decarboxylase (TYDC) or tyrosine hydroxylase (TH) (Kulma and Szopa, 2006; Rezaei et al., 2016), and the biosynthetic pathways of dopamine in plants resemble those in mammals (Liu Q. W. et al., 2020). However, dopamine biosynthesis pathways differ among plants. Dopamine is a water-soluble molecule with stronger antioxidant activity in plants than glutathione, similar to gallocatechin gallate and ascorbic acid (Kulma and Szopa, 2006). Dopamine also plays a critical role in the response of plants to abiotic stress, and can promote the growth of plants under various stressful environmental conditions (Liu Q. W. et al., 2020). More recent researches have reported that dopamine can enhance plant tolerance of drought, salt stress, and nutrient deficiency (Li et al., 2015; Liang et al., 2017, 2018a). In addition, exogenous dopamine was shown to increase the uptake of nutrients under drought stress conditions (Liang et al., 2018a). Recent studies have shown that $\mathrm{DOH}-\mathrm{CB}$ protein can bind to dopamine through the induction of auxin (Verelst and Asard, 2004). Therefore, DOH-CB protein may be the receptor of plant catecholamines, and the binding between them may be induced by auxin (Liu Q. W. et al., 2020).

Over the past decade, significant progress has been made in understanding how $\mathrm{NO}_{3}^{-}$absorption, transport, and assimilation are modulated (Kiba et al., 2012; Lezhneva et al., 2014; Wang Y. Y. et al., 2018), and how exogenous substances such as plant hormones play a role under low $\mathrm{N}$ conditions ( $\mathrm{Su}$ et al., 2020). However, the effects of melatonin and dopamine on the transcriptional regulation of genes related to $\mathrm{NO}_{3}^{-}$uptake and metabolism under low- $\mathrm{NO}_{3}{ }^{-}$stress have not been studied systematically to our knowledge. ${ }^{15} \mathrm{~N}$ labeling stable isotope technique can provide important insights into $\mathrm{N}$ uptake by roots from soil profiles (Shiva et al., 2016), and the effects of melatonin on nutrient absorption under drought conditions have been studied using ${ }^{15} \mathrm{~N}$ tracer (Liang et al., 2018b). Here, the research also described applied such tracers to study the effects of melatonin and dopamine on $\mathrm{N}$ uptake under low $\mathrm{NO}_{3}{ }^{-}$conditions.

Numerous studies have shown that melatonin and dopamine are involved in the response to various environmental stresses in plants, including nutrient deficiency (Li et al., 2016; Liu X. M. et al., 2020). To date, most studies have focused on enhancing the chlorophyll level, photosynthetic performance, and antioxidant enzyme activity associated with abiotic stress, less attention has been paid to nutrient utilization efficiency under low- $\mathrm{NO}_{3}{ }^{-}$ stress. Here, a hydroponics system was used to test whether the application of exogenous melatonin and dopamine has a positive effect on $M$. hupehensis under low- $\mathrm{NO}_{3}{ }^{-}$stress. We investigated photosynthesis, root system structure, ${ }^{15} \mathrm{NO}_{3}{ }^{-}$absorption and distribution, and related enzyme activity and gene expression with the aim to clarify the regulatory mechanisms of melatonin and dopamine on nutrient uptake and utilization under low$\mathrm{NO}_{3}{ }^{-}$stress. 


\section{MATERIALS AND METHODS}

\section{Plant Materials and Growing Conditions}

The research was conducted at Hebei Agricultural University, Baoding $\left(38^{\circ} 23^{\prime} \mathrm{N}, 115^{\circ} 28^{\prime} \mathrm{E}\right)$, Hebei, China. Triploid and apomixis-type $M$. hupehensis seeds were collected from Pingyi $\left(35^{\circ} 07^{\prime} \mathrm{N}, 117^{\circ} 25^{\prime} \mathrm{E}\right)$, Shandong, China. For seed germination, cold stratification was required for 50 days at $4^{\circ} \mathrm{C}$. After germination, three seeds were planted in each plastic pot filled with sand, and placed in a greenhouse under natural light and temperature conditions. The design of our hydroponic system was consistent with that of Liang et al. (2017). After 40 days of growth, we selected plants of similar size (8-9 leaves, about $8 \mathrm{~cm}$ high) and transferred them to plastic tubs wrapped with black plastic to block light exposure to the root systems containing $10 \mathrm{~L}$ of Hoagland semi-strength nutrient solution. We maintained the oxygen content in the nutrient solution by installing air pumps (Bai et al., 2010). The $\mathrm{pH}$ of the nutrient solution was adjusted to $6.5 \pm 0.1$ with $\mathrm{H}_{3} \mathrm{PO}_{4}$, and the solution was refreshed every 5 days.

\section{Experimental Design}

The melatonin and dopamine concentrations in our experiments were consistent with those described in our previous studies (Li et al., 2016; Liang et al., 2017, respectively). After 10 days of preconditioning, $M$. hupehensis seedlings supplied $\mathrm{K}^{15} \mathrm{NO}_{3}$ as the only source of $\mathrm{N}$ were divided into six experimental groups: control: $2 \mathrm{mM} \mathrm{K}{ }^{15} \mathrm{NO}_{3}$ solution (CK); $\mathrm{NO}_{3}{ }^{-}$-deficient treatment: $0.1 \mathrm{mM} \mathrm{K}^{15} \mathrm{NO}_{3}$ solution (ST); melatonin control: $2 \mathrm{mM} \mathrm{K}{ }^{15} \mathrm{NO}_{3}$ solution with $0.1 \mu \mathrm{mol} / \mathrm{L}$ melatonin (MCK); melatonin- and $\mathrm{NO}_{3}{ }^{-}$-deficient treatment: $0.1 \mathrm{mM} \mathrm{K} \mathrm{K}^{15} \mathrm{NO}_{3}$ solution with $0.1 \mu \mathrm{mol} / \mathrm{L}$ melatonin (MST); dopamine control: $2 \mathrm{mM} \mathrm{K}{ }^{15} \mathrm{NO}_{3}$ solution with $100 \mu \mathrm{mol} / \mathrm{L}$ dopamine (DCK); and dopamine- and $\mathrm{NO}_{3}{ }^{-}$-deficient treatment: $0.1 \mathrm{mM} \mathrm{K}{ }^{15} \mathrm{NO}_{3}$ solution with $100 \mu \mathrm{mol} / \mathrm{L}$ dopamine (DST). The $\mathrm{K}^{15} \mathrm{NO}_{3}$ was produced by the Shanghai Research Institute of Chemical Industry (abundance of 98.14\%). Each of the six groups included three replicates with 150 seedlings, and the trial spanned 20 days. Plant growth measurements were made on Days 0 and 20, while root architecture and enzyme activity were analyzed on Day 20. Chlorophyll concentrations and gene expression were determined on Days $0,5,10,15$, and 20. Fine roots and mature leaves were collected for different measurements, which included enzyme activity and gene expression.

\section{Growth Measurements}

The plant length (PL) and trunk diameter (TD) was measured after 20 days of treatment. The whole plant harvested from each treatment was divided into root, stem, and leaf sections. Then, each sample was fixed at $105^{\circ} \mathrm{C}$ for $15 \mathrm{~min}$ and oven-dried at $70^{\circ} \mathrm{C}$ for at least $72 \mathrm{~h}$ to determine the dry weight. The total dry weight (TDW) was defined as the sum of the dry mass of roots, stems, and leaves. The rootto-stem ratio (RSR) was calculated by dividing the root dry weight by the stem dry weight. The relative growth rate (RGR) was calculated by the equation of Liang et al. (2018a). After being individually ground and sieved, fully triturated samples of leaf, stem and root were used for determination of ${ }^{15} \mathrm{~N}$.

\section{Chlorophyll Extraction and Measurement}

The leaves in the middle of the plant were extracted with $80 \%$ acetone for more than $24 \mathrm{~h}$, and the pigment content was determined by spectrophotometry, as described by Arnon (1949).

\section{Investigation of Root Architecture}

The root systems were cleared of impurities, without damaging the systems, with tap water, distilled water, and double-steamed water. We used a scanner to image the root system and analyzed the root architecture via the $\mathrm{WinRHIZO}^{\circledR}$ image analysis system (V4.1c; Régent Instruments, QC, Canada).

\section{Determination of ${ }^{15} \mathrm{~N}$ Uptake Flux and Partitioning}

Nitrogen stable isotope ratio was determined using an elemental analyzer (Flash EA 1112HT, Thermo Fisher Scientific, Inc., United States) coupled with an isotope ratio mass spectrometer (Finnigan Delta V Advantage, Thermo Fisher Scientific, Inc.). The total content of ${ }^{15} \mathrm{~N}$ in a specific organ type (leaf, stem, or root) was calculated as the product of DW and the ${ }^{15} \mathrm{~N}$ concentration of each organ type. Over the 20 days stress period, the ${ }^{15} \mathrm{~N}$ uptake flux was calculated based on the RGR, DW, and total contents of ${ }^{15} \mathrm{~N}$ in the root, stem, and leaf according to the equation of Liang et al. (2017). Partitioning among leaves,

TABLE 1 | Sequences of primers used in qRT-PCR.

\begin{tabular}{|c|c|}
\hline Gene & Primer sequence $\left(5^{\prime}-3^{\prime}\right)$ \\
\hline$N R T 1: 1 \mathrm{~F}$ & CTGGCTGGTCCCACAGTTCTT \\
\hline$N R T 1: 1 \mathrm{R}$ & СTTCATTCCTITCGGGCACTC \\
\hline NRT2:4 F & CAGAAGGTGAACCCGGAAG \\
\hline NRT2:4 R & CAAGTGGAACGTCCTCATGTG \\
\hline NRT2:5 F & TTGTGGTCCATCTAAGAACAAGGC \\
\hline NRT2:5 R & TCATCAGAGGGTCGGGTAACAG \\
\hline NRT2:7 F & TCTCCAGGCAGACGAGCATT \\
\hline NRT2:7 R & GGAGCAAGTGATACTGGTTTGTTC \\
\hline NIRF & GTCCATCCGCAGAAACAAGAAG \\
\hline NIR R & GTTCCCCTGTGCCATACTCATC \\
\hline NRF & CGATGACGACGAGAATGAGGAC \\
\hline NRR & GCGGACCATAGACGAGTTACGAC \\
\hline GS F & ATATCTGCTGGAGATGAACTGTGG \\
\hline GS R & TGGACTTGGTGCTGTAGTITGTG \\
\hline NADH-GOGAT F & TGCCTAAGTTIATCAAGGTTATTCC \\
\hline NADH-GOGAT R & СTCATCTTCCTCCTCGTGCTCT \\
\hline$F d-G O G A T F$ & CGAAGGAAGAAGAAGACCACGC \\
\hline Fd-GOGAT R & TTGCTGGTGCCTGTTGGGTT \\
\hline$\beta$-Actin F & GGATTTGCTGGTGATGATGCT \\
\hline$\beta$-Actin R & AGTTGCTCACTATGCCGTGCT \\
\hline
\end{tabular}


TABLE 2 | Plant length (PL), trunk diameter (TD), leaf number (LN), total dry weight (TDW), root-to-shoot ratio (RSR), and relative growth rate (RGR) for plants grown 20 days under different $\mathrm{N}$ levels and material treatments.

\begin{tabular}{|c|c|c|c|c|c|c|}
\hline Treatment & PL (cm) & TD (mm) & LN (No. plant ${ }^{-1}$ ) & TDW (g plant ${ }^{-1}$ ) & RSR (\%) & $\operatorname{RGR}\left(g \mathrm{~kg}^{-1} \mathrm{~d}^{-1}\right)$ \\
\hline $\mathrm{CK}$ & $30.83 \pm 1.96^{a}$ & $2.33 \pm 0.12^{b}$ & $18.4 \pm 1.35^{a}$ & $2.28 \pm 0.15^{b}$ & $20.22 \pm 2.22^{c}$ & $62.90 \pm 3.24^{b c}$ \\
\hline ST & $20.52 \pm 1.52^{c}$ & $1.77 \pm 0.10^{d}$ & $12.3 \pm 1.06^{c}$ & $1.19 \pm 0.17^{d}$ & $29.58 \pm 5.52^{a b}$ & $29.90 \pm 7.30^{e}$ \\
\hline MCK & $31.02 \pm 1.73^{a}$ & $2.57 \pm 0.14^{a}$ & $17.9 \pm 1.52^{a}$ & $2.64 \pm 0.24^{a}$ & $19.74 \pm 1.43^{c}$ & $70.12 \pm 4.54^{a}$ \\
\hline MST & $23.14 \pm 1.95^{b}$ & $2.00 \pm 0.13^{c}$ & $14.3 \pm 1.16^{b}$ & $1.59 \pm 0.24^{c}$ & $29.18 \pm 4.62^{b}$ & $44.41 \pm 7.45^{d}$ \\
\hline DCK & $31.14 \pm 3.04^{a}$ & $2.64 \pm 0.23^{a}$ & $17.6 \pm 1.51^{a}$ & $2.55 \pm 0.11^{a}$ & $18.95 \pm 1.20^{c}$ & $68.52 \pm 2.25^{a b}$ \\
\hline DST & $24.84 \pm 0.60^{b}$ & $2.19 \pm 0.08^{b c}$ & $15.5 \pm 0.71^{b}$ & $2.18 \pm 0.14^{b}$ & $33.87 \pm 2.38^{a}$ & $60.77 \pm 3.31^{c}$ \\
\hline
\end{tabular}

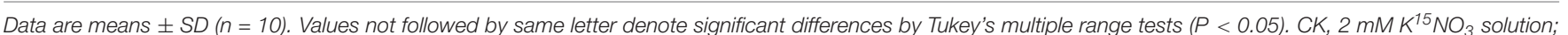

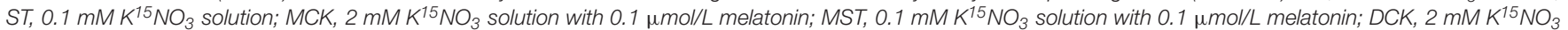
solution with $100 \mu \mathrm{mol} / \mathrm{L}$ dopamine; DST, $0.1 \mathrm{mM} \mathrm{K}^{15} \mathrm{NO}_{3}$ solution with $100 \mu \mathrm{mol} / \mathrm{L}$ dopamine.

stems, and roots was examined relative to the whole-plant contents of ${ }^{15} \mathrm{~N}$.

\section{Determination of the Activities of Enzymes Involved in N Assimilation}

Enzyme activities during the process of $\mathrm{N}$ assimilation were determined spectrophotometrically. The activity of NR was monitored in leaves and roots according to the in vitro method described by Högberg et al. (1986). The activity of NiR was measured based on a previously described method (Ogawa et al., 1999). The GS activity was measured according to the method of Claussen and Lenz (1999), and GOGAT was assayed by the method described by Lin and Kao (1996).

\section{Quantitative Real-Time Polymerase Chain Reaction Analysis}

Total RNA was extracted from leaf and root samples using an M5 Plant RNeasy Complex Mini Kit (Mei5 Biotechnology Co., Ltd., Beijing, China) according to the manufacturer's instructions. We performed reverse transcription using the UEIrisIIRT-PCR System for the First-Strand cDNA Synthesis System (Suzhou US Everbright, Inc., Suzhou, China). The expression levels of genes involved in $\mathrm{N}$ metabolism and uptake were measured by quantitative real-time polymerase chain reaction (qRT-PCR) (Table 1). The qRT-PCR was performed on a LightCycler 96 Real-Time PCR System (Roche Diagnostics, Basel, Switzerland) using the AugeGreen ${ }^{\text {TM }}$ qPCR Master Mix Kit (Suzhou US Everbright, Inc.) with $\beta$-actin as an internal standard. Three independent biological replicates were performed for each sample.

\section{Statistical Analysis}

All data were analyzed using IBM SPSS Statistics 20 software (IBM Corp, Armonk, NY, United States) and then graphed with SigmaPlot 10.0 software for Windows (Systat Software, Inc., San Jose, CA, United States). The means of the treatments were compared by one-way analysis of variance (ANOVA), and differences between treatments were evaluated using Tukey's multiple range test $(P<0.05)$.

\section{RESULTS}

\section{Effects of Exogenous Melatonin and Dopamine on Plant Growth}

Under low- $\mathrm{NO}_{3}{ }^{-}$stress, plant growth was severely inhibited in comparison with the normal control, leading to significant decreases in PL, TD, LN, TDW, and RGR of 33.4, 24.0, 33.2, 47.8 , and 52.5\%, respectively. However, exogenous melatonin and dopamine both significantly alleviated these declines compared with $\mathrm{NO}_{3}{ }^{-}$-deficient plants that had received no exogenous material. The values of PL, TD, LN, TDW, and RGR in the $\mathrm{NO}_{3}{ }^{-}$-deficient plants with $0.1 \mu \mathrm{mol} / \mathrm{L}$ exogenous melatonin were lower by $24.9,14.2,22.3,30.3$, and $29.4 \%$, respectively, than those for the normal control. For $\mathrm{NO}_{3}{ }^{-}$-deficient plants with $100 \mu \mathrm{mol} / \mathrm{L}$ exogenous dopamine, these growth indices were lower by only $19.4,6.0,15.8,4.4$, and $3.4 \%$, respectively. Therefore, both melatonin and dopamine significantly alleviated

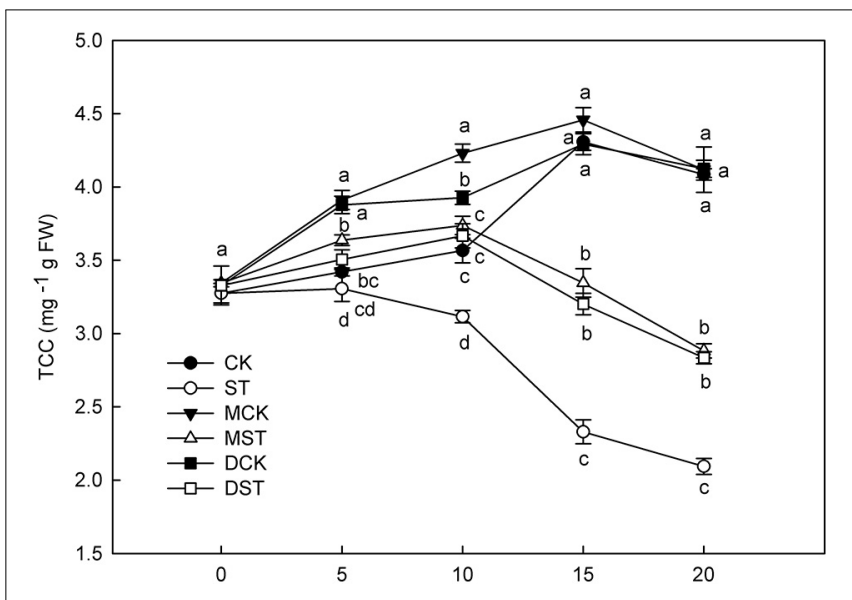

FIGURE 1 | Effect of melatonin and dopamine on total chlorophyll concentration (TCC) under different N levels and material treatments. Data are means \pm SD of five replicate samples. Values not followed by same letter denote significant differences by Tukey's multiple range tests $(P<0.05)$. CK, $2 \mathrm{mM} \mathrm{K}^{15} \mathrm{NO}_{3}$ solution; ST, $0.1 \mathrm{mM} \mathrm{K}{ }^{15} \mathrm{NO}_{3}$ solution; MCK, $2 \mathrm{mM} \mathrm{K}^{15} \mathrm{NO}_{3}$ solution with $0.1 \mu \mathrm{mol} / \mathrm{L}$ melatonin; $\mathrm{MST}, 0.1 \mathrm{mM} / \mathrm{L} \mathrm{K}^{15} \mathrm{NO}_{3}$ solution with $0.1 \mu \mathrm{mol} / \mathrm{L}$ melatonin; DCK, $2 \mathrm{mM} \mathrm{K}^{15} \mathrm{NO}_{3}$ solution with $100 \mu \mathrm{mol} / \mathrm{L}$ dopamine; DST, $0.1 \mathrm{mM} \mathrm{K}^{15} \mathrm{NO}_{3}$ solution with $100 \mu \mathrm{mol} / \mathrm{L}$ dopamine. 


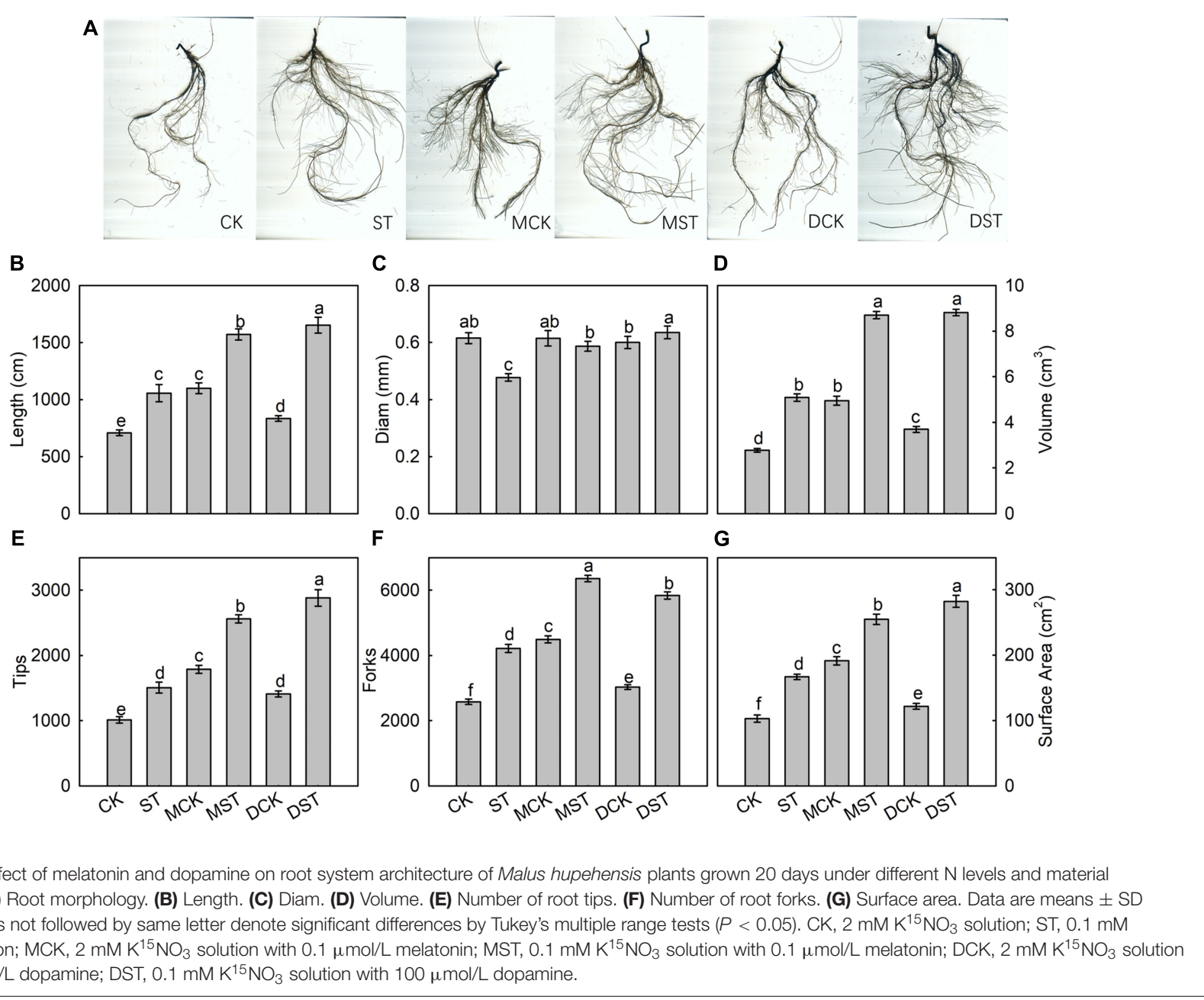

the inhibition attributable to low- $\mathrm{NO}_{3}{ }^{-}$stress, although the effect of $100 \mu \mathrm{mol} / \mathrm{L}$ exogenous dopamine was more obvious. Moreover, under the normal $\mathrm{NO}_{3}{ }^{-}$condition, melatonin and dopamine could also promote plant growth, but the effect was not as obvious as in the plants under the low $\mathrm{NO}_{3}{ }^{-}$ condition. In addition, due to the root foraging response, the RSR was increased significantly (by $46.3 \%$ ) under $\mathrm{NO}_{3}{ }^{-}$deficiency in comparison with the normal control, and this response was enhanced even more by the administration of exogenous dopamine (Table 2).

\section{Effects of Exogenous Melatonin and Dopamine on Chlorophyll Content}

$\mathrm{N}$ is a major element involved in the synthesis and metabolism of chlorophyll, and $\mathrm{NO}_{3}{ }^{-}$-deficiency triggers huge changes in total chlorophyll concentration. After 10 days of low $\mathrm{NO}_{3}{ }^{-}$treatment, the chlorophyll content began to decrease significantly, and the application of exogenous melatonin or dopamine significantly alleviated the degradation of chlorophyll (Figure 1). At Day 20, the total chlorophyll concentration increased by 37.6 and $35.4 \%$ in plants treated with melatonin and dopamine under low- $\mathrm{NO}_{3}{ }^{-}$ stress, respectively.

\section{Effects of Exogenous Melatonin and Dopamine on Root Architecture}

After 20 days of exposure to the $\mathrm{NO}_{3}{ }^{-}$-deficient nutrient solution, the root system architecture had changed significantly (Figure 2A). Compared with the normal control, the ST, MST, and DST plants exhibited increases of 49.0, 121.8, and $133.1 \%$ in total root length; $83.4,214.1$, and $218.1 \%$ in root volume; 48.9 , 153.3 , and $185.0 \%$ in the number of root tips; $63.5,146.8$, and $126.6 \%$ in root forks; and $61.9,147.5$, and $174.1 \%$ in surface area (Figures 2B,D-G). However, the root diameter of the ST and MST plants decreased by 22.6 and $4.8 \%$, respectively. In contrast, dopamine increased the root diameter by $3.2 \%$ (Figure 2C).

\section{Effects of Exogenous Melatonin and Dopamine on ${ }^{15} \mathrm{~N}$ Uptake and Distribution}

The $\mathrm{NO}_{3}{ }^{-}$-deficient treatment significantly reduced ${ }^{15} \mathrm{NO}_{3}{ }^{-}$ content in the whole plant (92.9\%), and also reduced ${ }^{15} \mathrm{NO}_{3}{ }^{-}$ uptake flux (96.6\%) compared with samples collected under the normal condition. Under low- $\mathrm{NO}_{3}{ }^{-}$stress, the accumulation of ${ }^{15} \mathrm{NO}_{3}{ }^{-}$was diminished in the leaf $(92.8 \%)$, stem (90.1\%), 
and root $(95.9 \%)$. In addition, the proportion of ${ }^{15} \mathrm{NO}_{3}{ }^{-}$ content in the stem compared to the whole plant decreased obviously under the low $\mathrm{NO}_{3}{ }^{-}$condition. However, exogenous melatonin or dopamine was associated with obvious increases in the uptake and accumulation of ${ }^{15} \mathrm{NO}_{3}{ }^{-}$under the $\mathrm{NO}_{3}{ }^{-}$deficient condition. When melatonin- and dopamine-treated plants were compared with no-material plants under the stress treatment, the ${ }^{15} \mathrm{NO}_{3}{ }^{-}$content were improved by 122.6 and $209.4 \%$, and the ${ }^{15} \mathrm{NO}_{3}{ }^{-}$uptake flux increased by 230.2 and $528.2 \%$, respectively. Furthermore, the accumulation and uptake of ${ }^{15} \mathrm{NO}_{3}{ }^{-}$increased in all parts of the plant (Figure 3). Under the low $\mathrm{NO}_{3}{ }^{-}$condition, exogenous melatonin most obviously promoted ${ }^{15} \mathrm{NO}_{3}{ }^{-}$accumulation in leaves in comparison with the no-material plants. The ${ }^{15} \mathrm{NO}_{3}{ }^{-}$content and ${ }^{15} \mathrm{NO}_{3}{ }^{-}$uptake flux increased by 141.8 and $259.6 \%$, respectively. Exogenous dopamine also significantly promoted ${ }^{15} \mathrm{NO}_{3}{ }^{-}$accumulation in leaves in comparison with the no-material plants. The ${ }^{15} \mathrm{NO}_{3}{ }^{-}$ content and ${ }^{15} \mathrm{NO}_{3}{ }^{-}$uptake flux increased by 210.5 and $532.0 \%$, respectively (Figure 3 ).

\section{Effects of Exogenous Melatonin and Dopamine on $\boldsymbol{N}$-Metabolizing Enzyme Activities}

Enzymes such as NR, NiR, GS, Fd-GOGAT, and NADHGOGAT play key roles in $\mathrm{NO}_{3}{ }^{-}$reduction and $\mathrm{N}$ assimilation, and their enzyme activities changed dramatically under the $\mathrm{NO}_{3}{ }^{-}$-deficient condition. After 20 days of the $\mathrm{NO}_{3}{ }^{-}$-deficient treatment, the enzyme activity results indicated that low $-\mathrm{NO}_{3}{ }^{-}$ stress sharply reduced the activities of NR, NiR, and Fd-GAGOT in leaf and root. In the comparison between normal control and stressed plants, the activities of NR, NiR, GS, and Fd-GAGOT declined by $66.7,34.3,13.3$, and $18.8 \%$ in leaf (Figures 4AD) and 67.4, 20.9, 1.8, and 14.2\% in root (Figures 5A-D), respectively. However, when melatonin or dopamine was applied to either the $\mathrm{NO}_{3}{ }^{-}$-normal or $\mathrm{NO}_{3}{ }^{-}$-deficient plants, the enzyme activity increased, especially in $\mathrm{NO}_{3}{ }^{-}$-deficient plants. By Day 20, the activities of NR, NiR, GS, and Fd-GOGAT in melatonin- and dopamine-treated leaves had increased by 130.1 and $171.7 \%, 45.2$ and $48.9 \%, 50.2$ and $230.7 \%$, and 10.8 and $25.3 \%$ (Figures 4A-D), respectively, in comparison with the corresponding no-material plants under low- $\mathrm{NO}_{3}{ }^{-}$stress. In root, the corresponding values were 85.7 and $111.7 \%, 14.5$ and $32.2 \%, 9.7$ and $30.2 \%$, and 28.9 and $27.9 \%$, respectively (Figures 5A-D). In addition, the activity of NADH-GOGAT declined by $42.2 \%$ in root (Figure 5E) and increased by $206.8 \%$ in leaf (Figure 4E); however, Fd-GOGAT is the enzyme that plays the major role in leaves. All of these results demonstrated that low- $\mathrm{NO}_{3}{ }^{-}$stress slowed the processes of $\mathrm{NO}_{3}{ }^{-}$reduction and $\mathrm{N}$ assimilation in leaves. However, supplementation with melatonin or dopamine substantially alleviated these responses, and dopamine was more effective than melatonin.

\section{Effects of Melatonin and Dopamine on Transcriptional Regulation of Genes Involved in N Metabolism and Transport}

Furthermore, we studied the internal molecular responses induced by low- $\mathrm{NO}_{3}{ }^{-}$stress, as demonstrated by the changing

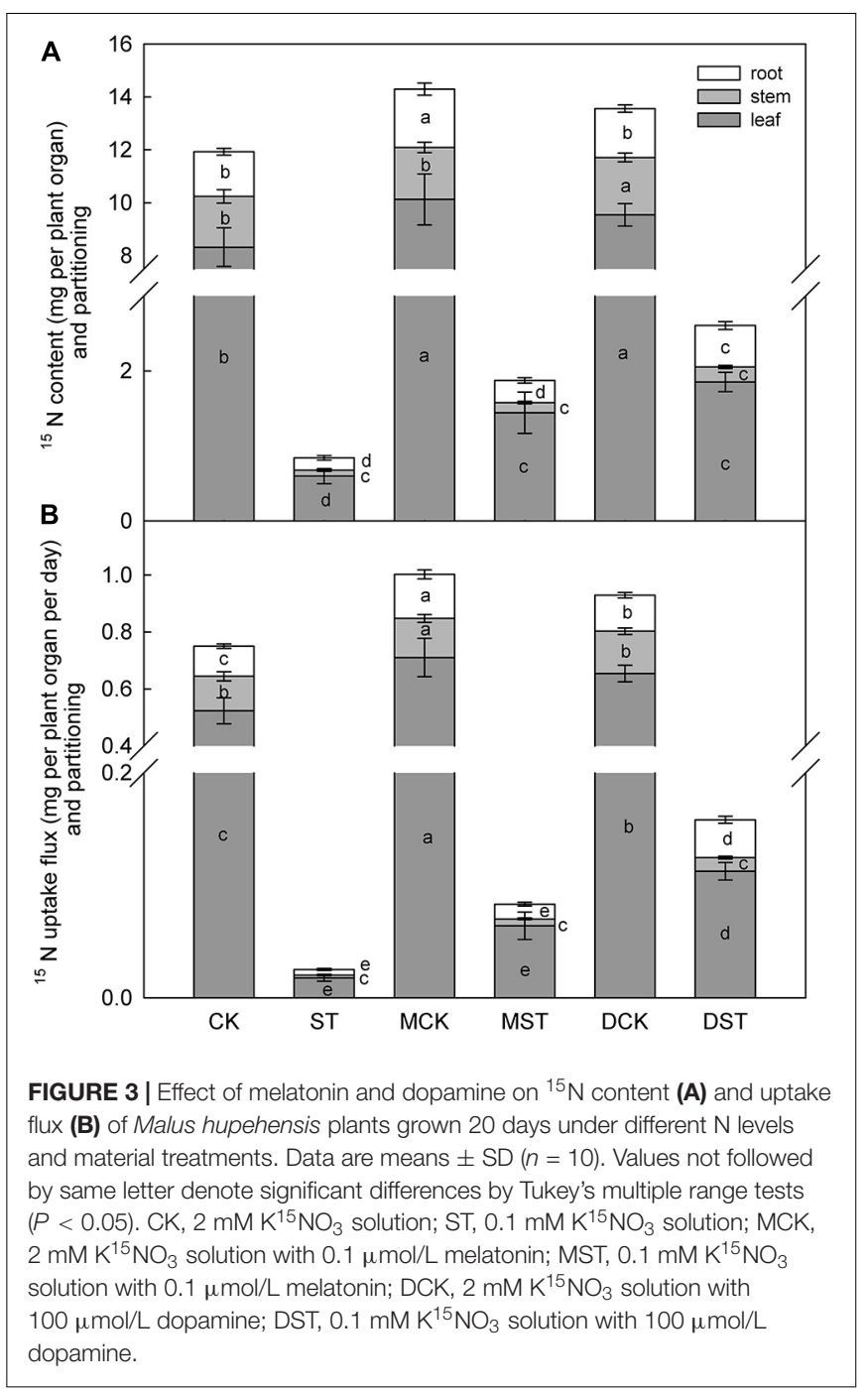

transcriptional regulation patterns of key genes implicated in $\mathrm{N}$ uptake and metabolism. After 5-10 days of exposure to the $\mathrm{NO}_{3}{ }^{-}$-deficient nutrient solution, we found that the transcript levels of all investigated genes related to $\mathrm{N}$ metabolism $(\mathrm{NR}, \mathrm{NiR}$, GS, NADH-GOGAT, and Fd-GAGOT) in the leaves and roots of the no-material plants were significantly lower than those of the normal control plants (Figures 6A-E, 7A-E). However, their relative expression was higher in the melatonin- and dopaminetreated plants than in the no-material plants, indicating that melatonin and dopamine promoted the expression of genes associated with $\mathrm{N}$ metabolism under the low $\mathrm{NO}_{3}{ }^{-}$condition (Figures 6A-E, 7A-E). In addition, we found that dopamine could especially increase the transcript levels of GS after 5 days of treatment (Figures 6C, 7C).

The expression of genes involved in regulating $\mathrm{NO}_{3}^{-}$ transport, that is, NRT2.4, NRT2.5, and NRT2.7, was significantly upregulated in response to $\mathrm{NO}_{3}{ }^{-}$deficiency in both leaves and roots; however, exogenous melatonin and dopamine amplified this enhancement effect and the relative expression levels were higher. Transcript levels peaked between days 10 and 15 of treatment, and the relative expression levels then gradually 


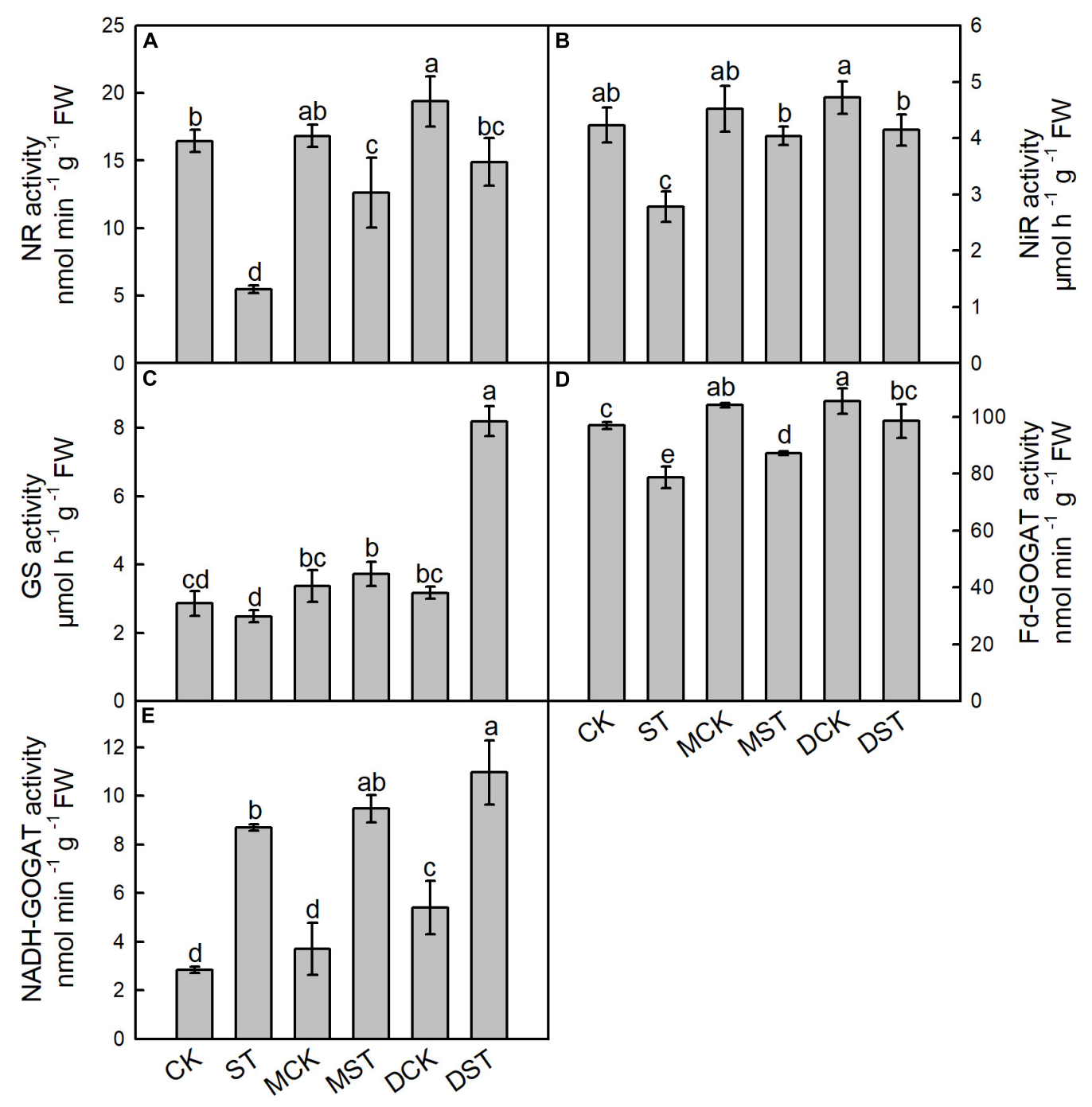

FIGURE 4 | Effects of melatonin and dopamine on activities of nitrate reductase (NR; $\mathbf{A})$, nitrite reductase (NiR; B), glutamine synthetase (GS; C),

ferredoxin-dependent glutamate synthase (Fd-GOGAT; D), and nicotinamide adenine dinucleotide (NADH-GOGAT; E) in leaves under different treatment conditions. Data are means $\pm \mathrm{SD}(n=3)$. Values not followed by same letter denote significant differences by Tukey's multiple range tests $(P<0.05)$. $\mathrm{CK}, 2 \mathrm{mM} \mathrm{K}{ }^{15} \mathrm{NO}_{3}$ solution; ST, $0.1 \mathrm{mM} \mathrm{K}^{15} \mathrm{NO}_{3}$ solution; MCK, $2 \mathrm{mM} \mathrm{K}^{15} \mathrm{NO}_{3}$ solution with $0.1 \mu \mathrm{mol} / \mathrm{L}$ melatonin; $\mathrm{MST}$, $0.1 \mathrm{mM} \mathrm{K}{ }^{15} \mathrm{NO}_{3}$ solution with $0.1 \mu \mathrm{mol} / \mathrm{L}$ melatonin; DCK, $2 \mathrm{mM} \mathrm{K}^{15} \mathrm{NO}_{3}$ solution with $100 \mu \mathrm{mol} / \mathrm{L}$ dopamine; DST, $0.1 \mathrm{mM} \mathrm{K}{ }^{15} \mathrm{NO}_{3}$ solution with $100 \mu \mathrm{mol} / \mathrm{L}$ dopamine.

declined (Figures $\mathbf{8 B}-\mathbf{D}, \mathbf{9 B}-\mathbf{D})$. In addition, the relative expression level of $\mathrm{N}$ transporter NRT1.1 was significantly upregulated in leaves, and exogenous melatonin and dopamine further promoted its upregulation under low- $\mathrm{NO}_{3}{ }^{-}$stress (Figure 8A), except in roots (Figure 9A).

\section{DISCUSSION}

$\mathrm{N}$ availability is usually an important limiting factor of plant growth, unless the root system forms a symbiotic relationship with N-fixing microorganisms. However, only a very small proportion $(0.00024 \%)$ of Earth's $\mathrm{N}$ is available for plants in the soil environment, as well as for microorganisms and animals (Viktor and Cramer, 2005). More than half of the world's population relies on crops grown with synthetic $\mathrm{N}$ fertilizers. Over the past century, reliable supplies of $\mathrm{N}$ and other nutrients necessary for plant growth have allowed farmers to dramatically increase crop yields per unit of land, boosting economic development and allowing populations to increase (Zhang et al., 2015). Unfortunately, crops can only use $30-50 \%$ of the $\mathrm{N}$ fertilizer applied to soil (Miller and Cramer, 2005). Thus, excessive use of $\mathrm{N}$ fertilizer increases planting costs, results in serious environmental pollution, and endangers crop growth and human health (Galloway et al., 2008). Increasing NUE is one of the most effective ways to increase crop productivity while reducing environmental degradation. However, such improvements are conditional not only on management innovations, but also on genetic breeding and understanding the important role of hormones 


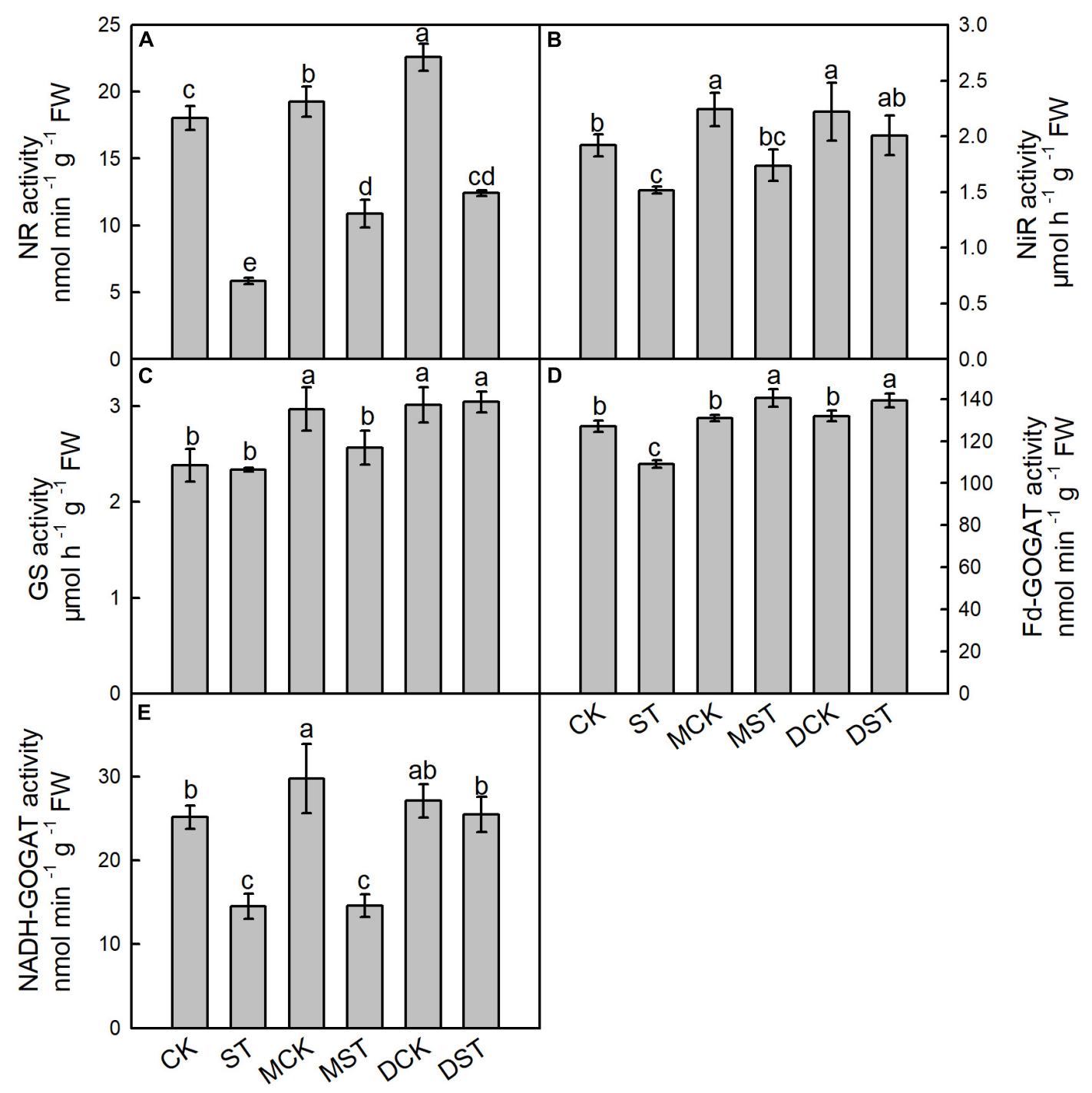

FIGURE 5 | Effects of melatonin and dopamine on activities of nitrate reductase (NR; $\mathbf{A})$, nitrite reductase (NiR; B), glutamine synthetase (GS; C), ferredoxin-dependent glutamate synthase (Fd-GOGAT; D), and nicotinamide adenine dinucleotide (NADH-GOGAT; E) in roots under different treatment conditions. Data are means $\pm \mathrm{SD}(n=3)$. Values not followed by same letter denote significant differences by Tukey's multiple range tests $(P<0.05)$. CK, 2 mM K ${ }^{15} \mathrm{NO}_{3}$ solution; ST, $0.1 \mathrm{mM} \mathrm{K}^{15} \mathrm{NO}_{3}$ solution; MCK, $2 \mathrm{mM} \mathrm{K}^{15} \mathrm{NO}_{3}$ solution with $0.1 \mu \mathrm{mol} / \mathrm{L}$ melatonin; $\mathrm{MST}, 0.1 \mathrm{mM} \mathrm{K}{ }^{15} \mathrm{NO}_{3}$ solution with $0.1 \mu \mathrm{mol} / \mathrm{L}$ melatonin; DCK, $2 \mathrm{mM} \mathrm{K}^{15} \mathrm{NO}_{3}$ solution with $100 \mu \mathrm{mol} / \mathrm{L}$ dopamine; DST, $0.1 \mathrm{mM} \mathrm{K}^{15} \mathrm{NO}_{3}$ solution with $100 \mu \mathrm{mol} / \mathrm{L}$ dopamine.

and other substances in the plant $\mathrm{N}$ cycle. Therefore, we examined the effects of melatonin and dopamine on the growth, photosynthesis, root system structure, and $\mathrm{N}$ metabolism of $\mathrm{NO}_{3}{ }^{-}$-deficient $M$. hupehensis seedlings.

Growth inhibition is an important indicator of environmental stress in plants. Li et al. (2016) reported that $0.1 \mu \mathrm{mol} / \mathrm{L}$ melatonin promoted plant growth under K-deficiency stress. Additionally, the application of $100 \mu \mathrm{mol} / \mathrm{L}$ exogenous dopamine reduced the inhibitory effect of $\mathrm{N}$ deficiency on plant growth significantly (Liu X. M. et al., 2020). However, this is the first systematic study on how melatonin and dopamine ameliorate the effects of low- $\mathrm{NO}_{3}{ }^{-}$stress in $M$. hupehensis. We found that the growth indicators were significantly lower in $\mathrm{NO}_{3}{ }^{-}$-deficient plants than in plants grown under normal conditions. This result was similar to the observations of previous studies (e.g., Liu X. M. et al., 2020). However, the application of exogenous melatonin and dopamine markedly mitigated these reductions, and dopamine was the more effective of the two. In addition, $\mathrm{NO}_{3}{ }^{-}$deficiency can promote root growth and thus increase the absorption area. This phenomenon is called the root foraging response (Giehl et al., 2014). We found that the RSR increased significantly (by $46.3 \%$ ) in comparison with the normal control under $\mathrm{NO}_{3}{ }^{-}$deficiency, and that this response was enhanced by the administration of exogenous dopamine.

Chlorophyll is the main photosynthetic pigment in green plants and algae, but is easily destroyed during photosynthesis and under environmental stress. Therefore, it is essential to maintain functional chlorophyll for the growth and development 


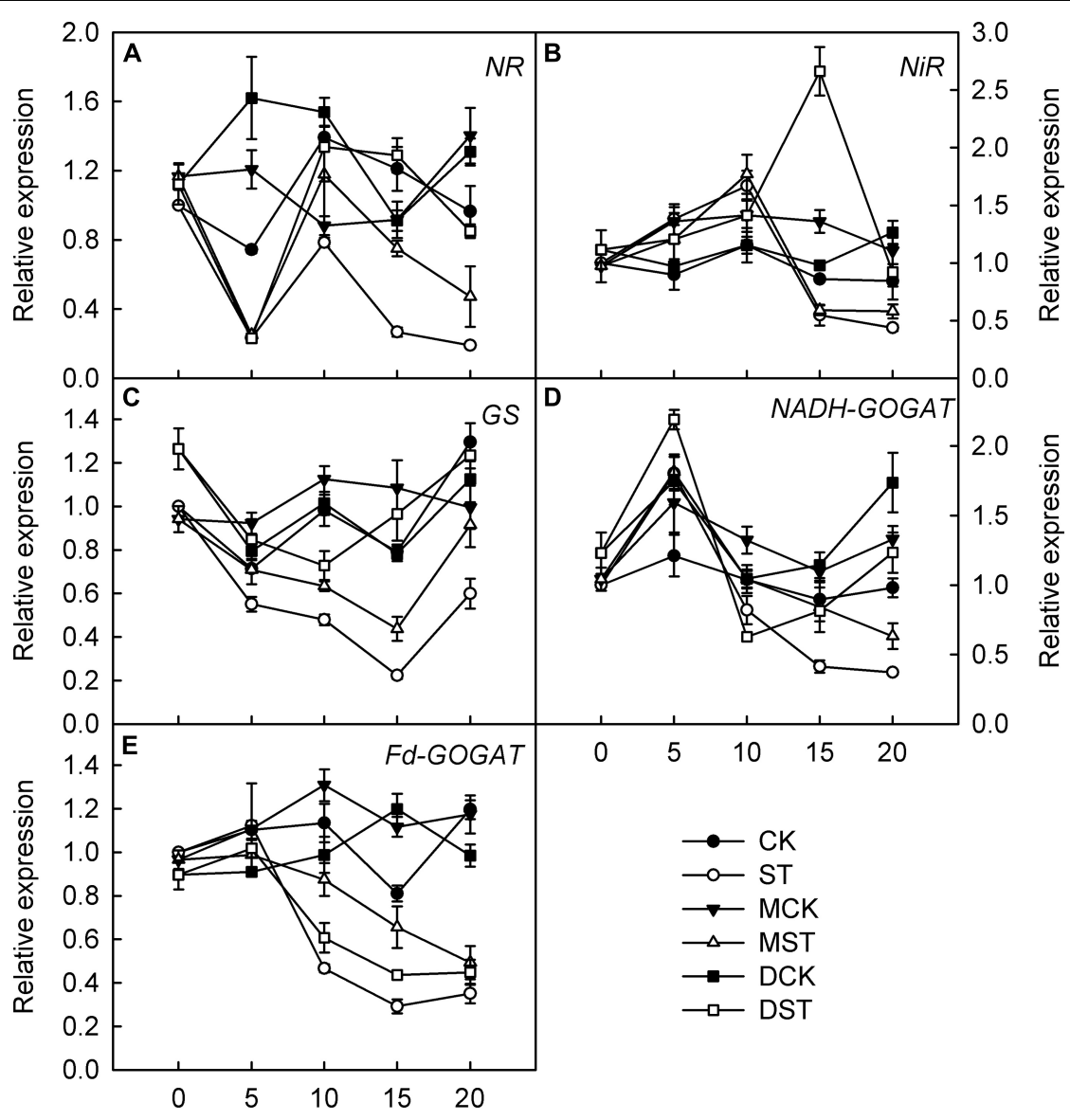

FIGURE 6 | Effects of melatonin and dopamine on expression of key genes involved in N-assimilation in leaves under different treatment conditions. (A) NR. (B) NiR. (C) GS. (D) NADH-GOGAT. (E) Fd-GOGAT. Total RNA was isolated from samples at specified time points (0-20 days), converted to cDNA, and subjected to qRT-PCR. Data are means $\pm \mathrm{SD}(n=3)$. CK, $2 \mathrm{mM} \mathrm{K}^{15} \mathrm{NO}_{3}$ solution; ST, $0.1 \mathrm{mM} \mathrm{K}^{15} \mathrm{NO}_{3}$ solution; MCK, $2 \mathrm{mM} \mathrm{K}^{15} \mathrm{NO}_{3}$ solution with $0.1 \mu$ mol/L melatonin; MST, $0.1 \mathrm{mM} \mathrm{K}^{15} \mathrm{NO}_{3}$ solution with $0.1 \mu \mathrm{mol} / \mathrm{L}$ melatonin; DCK, $2 \mathrm{mM} \mathrm{K}^{15} \mathrm{NO}_{3}$ solution with $100 \mu \mathrm{mol} / \mathrm{L}$ dopamine; DST, $0.1 \mathrm{mM} \mathrm{K}{ }^{15} \mathrm{NO}_{3}$ solution with $100 \mu \mathrm{mol} / \mathrm{L}$ dopamine.

of plants. $\mathrm{N}$ is an important component of chlorophyll, and a lack of $\mathrm{N}$ hinders chlorophyll synthesis, resulting in the yellowing of leaves and weakening (or even cessation) of photosynthesis (Liu X. M. et al., 2020). In this study, exogenous melatonin and dopamine can protect plants from the damage caused by low- $\mathrm{NO}_{3}{ }^{-}$stress, by maintaining high concentrations of photosynthetic pigment. Furthermore, recent research has shown that this result can be attributed to downregulation by melatonin of the genes involved in chlorophyll metabolism (CHLASE, $P P H, P A O$, and Chl-PRX) (Arnao and Hernandez-Ruiz, 2014; Sharma et al., 2020), and to the fact that melatonin also increases the biosynthesis of carotenoids by upregulating genes in the carotenoid biosynthetic pathway, phytoene synthase 1 (PSY1) and carotenoid isomerase (CRTISO) (Sun et al., 2015). In addition, exogenous dopamine had strong inhibitory effects on the upregulation of the chlorophyll degradation gene (Shiva et al., 2016) and senescence-associated gene under drought conditions (Liang et al., 2018a). All of these results verify the protective effects of melatonin and dopamine on plant photosynthesis under stress conditions at the molecular level.
Root developmental plasticity is essential for optimizing $\mathrm{NO}_{3}{ }^{-}$capture in continuously changing and $\mathrm{NO}_{3}{ }^{-}$ deficient soil environments (Gifford et al., 2013). Plant roots preferentially colonize $\mathrm{N}$-rich regions through directed lateral root development in growth substrates with uneven $\mathrm{N}$ availability. Several studies have found that $\mathrm{NO}_{3}{ }^{-}$mainly stimulates lateral root elongation and that $\mathrm{NH}_{4}{ }^{+}$induces lateral root branching, supporting the view that the root configurations promoted by the two main inorganic forms of $\mathrm{N}$ are mutually complementary (Zhang and Forde, 1998; Ying and Nicolaus, 2017). Under nutrient deficiency, plant roots adapt by constantly adjusting their physiological and structural characteristics, and the degree of adaptation depends on their ability to change their configuration (Jia et al., 2019). Moreover, several root architecture responses are related to changes in phytohormone flux or balance. In particular, adaptive responses of roots to different nutrient supplies can be induced by changing the auxin transport or signal transduction (Giehl et al., 2012). However, melatonin and auxin are synthesized with tryptophan as a precursor, and studies have shown that both melatonin 


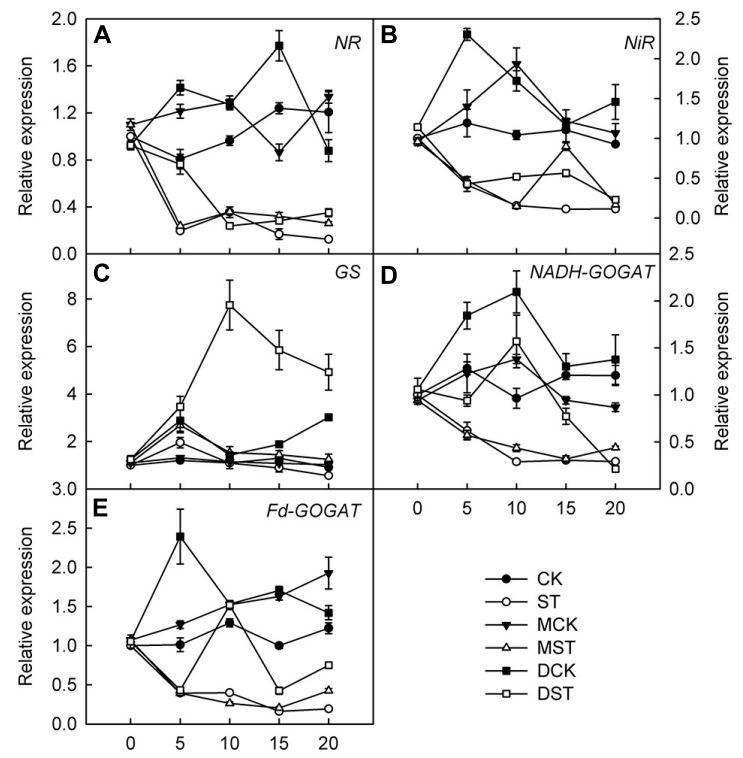

FIGURE 7 | Effects of melatonin and dopamine on expression of key genes involved in $\mathrm{N}$-assimilation in roots under different treatment conditions. (A) NR. (B) NiR. (C) GS. (D) NADH-GOGAT. (E) Fd-GOGAT. Total RNA was isolated from samples at specified time points (0-20 d), converted to cDNA, and subjected to qRT-PCR. Data are means $\pm \mathrm{SD}(n=3)$. CK, $2 \mathrm{mM} \mathrm{K}^{15} \mathrm{NO}_{3}$ solution; ST, $0.1 \mathrm{mM} \mathrm{K}^{15} \mathrm{NO}_{3}$ solution; MCK, $2 \mathrm{mM} \mathrm{K}^{15} \mathrm{NO}_{3}$ solution with $0.1 \mu \mathrm{mol} / \mathrm{L}$ melatonin; MST, $0.1 \mathrm{mM} \mathrm{K}^{15} \mathrm{NO}_{3}$ solution with $0.1 \mu \mathrm{mol} / \mathrm{L}$ melatonin; DCK, $2 \mathrm{mM} \mathrm{K}^{15} \mathrm{NO}_{3}$ solution with $100 \mu \mathrm{mol} / \mathrm{L}$ dopamine; DST, $0.1 \mathrm{mM} \mathrm{K}^{15} \mathrm{NO}_{3}$ solution with $100 \mu \mathrm{mol} / \mathrm{L}$ dopamine.

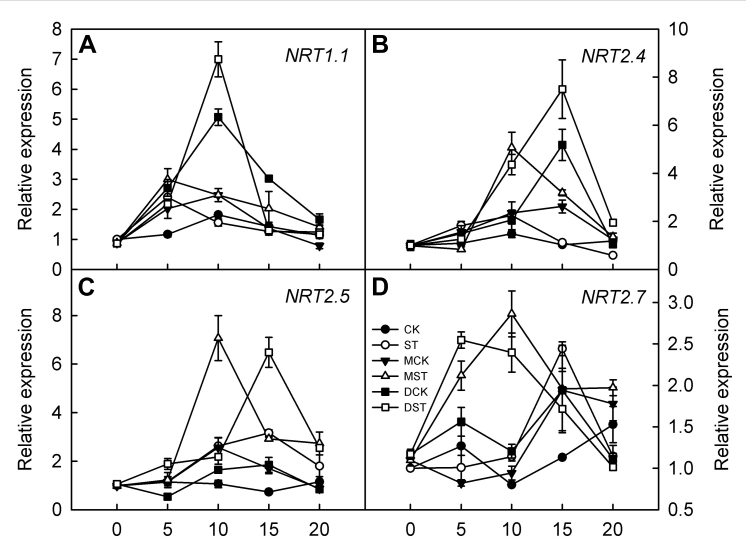

FIGURE 8 | Effects of melatonin and dopamine on expression of key genes involved in $\mathrm{N}$-uptake in leaves under different treatment conditions. (A) NRT1.1. (B) NRT2.4. (C) NRT2.5. (D) NRT2.7. Total RNA was isolated from samples at specified time points (0-20 days), converted to cDNA, and subjected to qRT-PCR. Data are means $\pm \mathrm{SD}(n=3)$. CK, $2 \mathrm{mM} \mathrm{K}^{15} \mathrm{NO}_{3}$ solution; ST, $0.1 \mathrm{mM} \mathrm{K}^{15} \mathrm{NO}_{3}$ solution; $\mathrm{MCK}, 2 \mathrm{mM} \mathrm{K}^{15} \mathrm{NO}_{3}$ solution with $0.1 \mu \mathrm{mol} / \mathrm{L}$ melatonin; MST, $0.1 \mathrm{mM} \mathrm{K}^{15} \mathrm{NO}_{3}$ solution with $0.1 \mu \mathrm{mol} / \mathrm{L}$ melatonin; DCK, 2 mM K ${ }^{15} \mathrm{NO}_{3}$ solution with $100 \mu \mathrm{mol} / \mathrm{L}$ dopamine; DST, $0.1 \mathrm{mM} \mathrm{K}^{15} \mathrm{NO}_{3}$ solution with $100 \mu \mathrm{mol} / \mathrm{L}$ dopamine.

and dopamine regulate the expression of various factors (enzymes, receptors, and transcription factors) participating in phytohormone biosynthesis and catabolism, such as of auxins

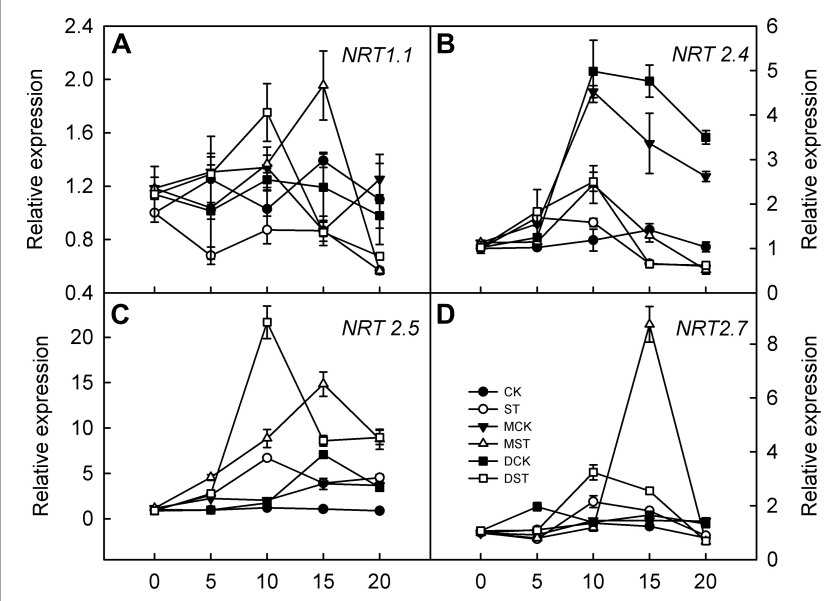

FIGURE 9 | Effects of melatonin and dopamine on expression of key genes involved in $\mathrm{N}$-uptake in roots under different treatment conditions. (A) NRT1.1. (B) NRT2.4. (C) NRT2.5. (D) NRT2.7. Total RNA was isolated from samples at specified time points (0-20 days), converted to cDNA, and subjected to qRT-PCR. Data are means $\pm \mathrm{SD}(n=3)$. $\mathrm{CK}, 2 \mathrm{mM} \mathrm{K}^{15} \mathrm{NO}_{3}$ solution; ST, $0.1 \mathrm{mM} \mathrm{K}^{15} \mathrm{NO}_{3}$ solution; MCK, $2 \mathrm{mM} \mathrm{K}^{15} \mathrm{NO}_{3}$ solution with $0.1 \mu \mathrm{mol} / \mathrm{L}$ melatonin; MST, $0.1 \mathrm{mM} \mathrm{K}^{15} \mathrm{NO}_{3}$ solution with $0.1 \mu \mathrm{mol} / \mathrm{L}$ melatonin; DCK, $2 \mathrm{mM} \mathrm{K}^{15} \mathrm{NO}_{3}$ solution with $100 \mu \mathrm{mol} / \mathrm{L}$ dopamine; DST, $0.1 \mathrm{mM} \mathrm{K}^{15} \mathrm{NO}_{3}$ solution with $100 \mu \mathrm{mol} / \mathrm{L}$ dopamine.

(Wang et al., 2016), gibberellins (Zhang et al., 2014), and abscisic acid and ethylene (Liu X. M. et al., 2020). Therefore, the application of exogenous melatonin or dopamine significantly promotes root system development and favors $\mathrm{N}$ absorption by plants under the $\mathrm{NO}_{3}{ }^{-}$-deficient condition. Under low nitrate conditions, the root system architecture had changed significantly. However, the total root length, root volume, the numbers of root tips, and surface area were higher in the dopamine treated plants than in the melatonin treated plants. This may lead to greater effectiveness of dopamine under nitrate stress in comparison to melatonin.

Various studies have suggested that nutrient uptake and transport by plants are generally inhibited by various abiotic stresses (Sánchez-Rodríguez et al., 2010; Kanwar et al., 2018; Qi et al., 2019). Exogenous melatonin has been shown to enable stressed plants to maintain significantly higher $\mathrm{K}$ levels in leaves in comparison to plants not exposed to melatonin under $\mathrm{K}$ - and all nutrient-deficient conditions ( $\mathrm{Li}$ et al., 2016). Furthermore, excess $\mathrm{NO}_{3}{ }^{-}$has been shown to reduce levels of phosphorus and magnesium, although this is usually mitigated by exogenous melatonin (Zhang et al., 2017). Similarly, exogenous dopamine can alleviate the inhibitory effects of nutrient deficiency on the absorption and accumulation of large and trace elements under salt stress (Li et al., 2015), and also prominently increases the concentrations, uptake, and transport of nutrients, while simultaneously altering their distribution within the whole plant, under drought conditions (Liang et al., 2018a). Through an investigation of stable isotopes, Liang et al. (2018b) confirmed that the concentration, uptake activity, and utilization rate of $\delta^{15} \mathrm{~N}$ were obviously increased by the addition of exogenous melatonin under drought stress. We also 
investigated stable isotopes to determine the ${ }^{15} \mathrm{NO}_{3}{ }^{-}$content: the ${ }^{15} \mathrm{NO}_{3}{ }^{-}$uptake flux was obviously increased by the addition of exogenous melatonin or dopamine under the low $\mathrm{NO}_{3}{ }^{-}$ condition. The $\mathrm{NO}_{3}{ }^{-}$-deficient treatment significantly reduced the concentration of ${ }^{15} \mathrm{NO}_{3}{ }^{-}$in the whole plant after 20 days, and also reduced ${ }^{15} \mathrm{NO}_{3}{ }^{-}$uptake flux in comparison with plants under the normal condition. In addition, the proportion of ${ }^{15} \mathrm{NO}_{3}{ }^{-}$in the stem relative to that in the whole plant decreased obviously under the low $\mathrm{NO}_{3}{ }^{-}$condition. The accumulation of $\mathrm{N}$ in roots and leaves is beneficial for the maintenance of normal plant growth. Exogenous melatonin and dopamine both distinctly increased the uptake and accumulation of ${ }^{15} \mathrm{NO}_{3}{ }^{-}$ under $\mathrm{NO}_{3}{ }^{-}$deficiency. Moreover, the accumulation and uptake of ${ }^{15} \mathrm{NO}_{3}{ }^{-}$increased in all parts of the plant, and exogenous melatonin very obviously promoted ${ }^{15} \mathrm{NO}_{3}{ }^{-}$accumulation in leaves in comparison with the no-material plants under the low$\mathrm{NO}_{3}{ }^{-}$stress condition. However, exogenous dopamine was more effective at promoting $\mathrm{N}$ accumulation, and the effect was most striking in roots. This phenomenon is well explained by the only slight increase in root diameter, and by the fact that the RSR was enhanced even more significantly by the administration of exogenous dopamine under the $\mathrm{NO}_{3}{ }^{-}$-deficient condition. Therefore, melatonin and dopamine not only promoted ${ }^{15} \mathrm{NO}_{3}{ }^{-}$ absorption in the whole plant, but also altered the ${ }^{15} \mathrm{NO}_{3}{ }^{-}$ distribution among the plant groups.

For many plants, after $\mathrm{NO}_{3}{ }^{-}$is absorbed into the root, $\mathrm{NO}_{3}{ }^{-}$ accumulation in the root is limited; most of it is transported to the aboveground parts, where the first step is reduction of $\mathrm{NO}_{3}{ }^{-}$to $\mathrm{NO}_{2}{ }^{-}$by $\mathrm{NO}_{3}{ }^{-}$reductase in the cytoplasm, followed by reduction to $\mathrm{NH}_{4}{ }^{+}$via $\mathrm{NO}_{3}{ }^{-}$reductase in the plastids (Wang et al., 2008). The $\mathrm{NH}_{4}{ }^{+}$reduced from $\mathrm{NO}_{3}{ }^{-}$is assimilated into amino acids by the GS/GOGAT cycle, which is a crucial step for converting inorganic $\mathrm{N}$ into organic $\mathrm{N}$ in plants, and the predominant GS/GOGAT isoenzymes are chloroplastic GS2/Fd-GOGAT and cytosolic GS1/NADH-GOGAT (Xu et al., 2012). Liu X. M. et al. (2020) confirmed that the activities of $\mathrm{NR}, \mathrm{NiR}, \mathrm{GS}$, and GOGAT were decreased to varying degrees under $\mathrm{NO}_{3}{ }^{-}$deficiency stress in $M$. hupehensis plants. Similarly, our data showed that the activities of key enzymes involved in $\mathrm{N}$ assimilation were decreased under the $\mathrm{NO}_{3}{ }^{-}$-deficient conditions. However, when exogenous melatonin or dopamine was applied to either $\mathrm{NO}_{3}{ }^{-}$-normal or $\mathrm{NO}_{3}{ }^{-}$-deficient plants, enzyme activity increased, in comparison to the untreated plants. And the activities of key enzymes involved in $\mathrm{N}$ assimilation were higher in the dopamine treated plants than in the melatonin treated plants, both in leaf and root. Our results demonstrate that melatonin and dopamine improve the uptake of $\mathrm{NO}_{3}{ }^{-}$in $M$. hupehensis plants by enhancing the activities of key enzymes involved in $\mathrm{N}$ assimilation, so that plants can absorb and use $\mathrm{N}$ better under $\mathrm{NO}_{3}{ }^{-}$-deficient conditions, and the effect of dopamine may be better.

In addition, we studied the internal molecular responses induced by low- $\mathrm{NO}_{3}{ }^{-}$stress, including the transcript levels of genes related to $\mathrm{N}$ metabolism and uptake in plant leaf and root. Melatonin has been shown to promote the expression of genes involved in $\mathrm{N}$ metabolism, thus relieving the inhibition induced by drought stress (Liang et al., 2018b). Similarly, we found that both melatonin and dopamine enhanced the expression of $\mathrm{NR}, \mathrm{NiR}, \mathrm{GS}, \mathrm{Fd}-\mathrm{GOGAT}$, and $\mathrm{NADH}-$ GOGAT under low- $\mathrm{NO}_{3}{ }^{-}$stress. Previous research identified 53 NRT1 genes and 7 NRT2 genes in the Arabidopsis thaliana genome. Most NRT1 transporters display low affinity for $\mathrm{NO}_{3}{ }^{-}$, although NRT1.1/NPF6.3/CHLORATE RESISTANT 1 (CHL1), the first $\mathrm{NO}_{3}{ }^{-}$transporter discovered in plants, exhibits a characteristic dual affinity (Tsay et al., 1993; Su et al., 2020). AtNRT1.1 has the capacity to transport multiple substrates. It not only uptakes $\mathrm{NO}_{3}{ }^{-}$for plant growth, but also reveals auxin transport activity and participates in $\mathrm{NO}_{3}{ }^{-}$-modulated root development (Krouk et al., 2010; Zhang et al., 2019). However, we did not observe significant upregulation at the transcription level of NRT1.1 in roots, and neither melatonin nor dopamine increased the transcription level of NRT1.1 significantly. In addition, AtNRT1.1 is also strongly expressed in guard cells, which regulate stomatal opening and thus affect transpiration (Guo et al., 2003). In leaves, drought stress has been shown to inhibit the transcript levels of NRT1.1, and exogenous melatonin has been shown to promote the expression of genes associated with NRT1.1 (Liang et al., 2018b). We found that NRT1.1 transcription was significantly upregulated, and that exogenous melatonin and dopamine enhanced the transcription of NRT1.1 in leaves, which could contribute to the maintenance of photosynthesis in $\mathrm{NO}_{3}{ }^{-}$deficient plants.

In general, NRT2s exhibit high-affinity $\mathrm{NO}_{3}{ }^{-}$transport activity when expressed in oocytes; however, some may exhibit only low-affinity $\mathrm{NO}_{3}{ }^{-}$transport activity (Fu et al., 2015). ATNRT2.1 is a high-affinity $\mathrm{NO}_{3}{ }^{-}$uptake gene in A. thaliana (Cerezo et al., 2001). Moreover, AtNRT2.4 and AtNRT2.5 also participate in high-affinity $\mathrm{NO}_{3}{ }^{-}$uptake (Kiba et al., 2012). AtNRT2.5 expression is strongly induced, and it becomes the primary transporter for high-affinity uptake after a long period of $\mathrm{NO}_{3}{ }^{-}$deficiency (Lezhneva et al., 2014). After 5 days of low $\mathrm{NO}_{3}{ }^{-}$treatment, we discovered that the expression levels of NRT2.4 and NRT2.5 first increased, and then decreased, in both leaf and root. The peaks occurred on day 10 or 15. However, exogenous melatonin and dopamine strongly upregulated NRT2.4 and NRT2.5 leaf and root. In addition, NRT2.7 is a seed-specific, high-affinity $\mathrm{NO}_{3}{ }^{-}$transporter that controls $\mathrm{NO}_{3}{ }^{-}$content in mature seeds of $A$. thaliana, and has been shown to be related to the accumulation and oxidation of proanthocyanidins (Liang et al., 2015). Some studies have found that melatonin can upregulate the expression of NRT2.7 in plants under drought stress (Huang et al., 2018; Liang et al., 2018b). Our results revealed that exogenous melatonin and dopamine can significantly upregulate the transcription levels of NRT2.7 in M. hupehensis. The aforementioned results indicate that both melatonin and dopamine regulate the expression of genes involved in N-metabolism and uptake in M. hupehensis seedlings under the low $\mathrm{NO}_{3}{ }^{-}$condition, thereby maintaining their growth and development.

\section{CONCLUSION}

This study confirmed that melatonin and dopamine can both alleviate the inhibition of plant growth and development, 
chlorophyll degradation, and decreased $\mathrm{N}$ uptake caused by low $-\mathrm{NO}_{3}{ }^{-}$stress. Moreover, these substances both have the ability to significantly change root architecture and effectively upregulate the expression levels of genes involved in $\mathrm{N}$-metabolism and transport in comparison with plants without any allogenic material under low $-\mathrm{NO}_{3}-$ stress. We systematically investigated the ability of dopamine and melatonin, as potential plant hormones, to increase NUE in $M$. hupehensis under low- $\mathrm{NO}_{3}{ }^{-}$stress. Further exploration of the roles of melatonin and dopamine in nutrient absorption may improve agriculture in the future.

\section{DATA AVAILABILITY STATEMENT}

The original contributions presented in the study are included in the article/supplementary material, further inquiries can be directed to the corresponding author/s.

\section{REFERENCES}

Arnao, M. B., and Hernandez-Ruiz, J. (2014). Melatonin: plant growth regulator and/or biostimulator during stress? Trends Plant Sci. 19, 789-797. doi: 10.1016/ j.tplants.2014.07.006

Arnao, M. B., and Hernandez-Ruiz, J. (2019). Melatonin: a new plant hormone and/or a plant master regulator? Trends Plant Sci. 24, 38-48. doi: 10.1016/j. tplants.2018.10.010

Arnon, D. I. (1949). Copper enzymes in isolated chloroplasts. polyphenoloxidase in Beta Vulgaris. Plant Physiol. 24, 1-15. doi: 10.1104/pp.24.1.1

Bai, T. H., Li, C. Y., Ma, F. W., Feng, F. J., and Shu, H. R. (2010). Responses of growth and antioxidant system to root-zone hypoxia stress in two Malus species. Plant Soil. 327, 95-105. doi: 10.1007/s11104-009-0034-x

Cerezo, M., Tillard, P., Filleur, S., Muños, S., Daniel-Vedele, F., and Gojon, A. (2001). Major alterations of the regulation of root $\mathrm{NO}_{3}{ }^{-}$uptake are associated with the mutation of Nrt2.1 and Nrt2.2 genes in Arabidopsis. Plant physiol. 127, 262-271. doi: 10.1104/pp.127.1.262

Claussen, W., and Lenz, F. (1999). Effect of ammonium or nitrate nutrition on net photosynthesis, growth, and activity of the enzymes nitrate reductase and glutamine synthetase in blueberry, raspberry and strawberry. Plant Soil 208, 95-102.

Dubbels, R., Reiter, R. J., Klenke, E., Goebel, A., Schnakenberg, E., Ehlers, C., et al. (1995). Melatonin in edible plants identified by radioimmunoassay and by high performance liquid chromatography-mass spectrometry. J. Pineal Res. 18, 28-31. doi: 10.1111/j.1600-079x.1995.tb00136.x

Fu, Y. L., Yi, H. Y., Bao, J., and Gong, J. M. (2015). LeNRT2.3 functions in nitrate acquisition and long-distance transport in tomato. FEBS. Lett. 589, 1072-1079. doi: 10.1016/j.febslet.2015.03.016

Galloway, J. N., Townsend, A. R., Erisman, J. W., Bekunda, M., Cai, Z., Freney, J. R., et al. (2008). Transformation of the nitrogen cycle: recent trends, questions, and potential solutions. Science 320, 889-892. doi: 10.1126/science.1136674

Giehl, R. F. H., Gruber, B. D., and von Wiren, N. (2014). It's time to make changes: modulation of root system architecture by nutrient signals. J. Exp. Bot. 65, 769-778. doi: 10.1093/jxb/ert421

Giehl, R. F. H., Lima, J. E., and von Wiren, N. (2012). Localized iron supply triggers lateral root elongation in Arabidopsis by altering the AUX1-mediated auxin distribution. Plant Cell 24, 33-49. doi: 10.1105/tpc.111.092973

Gifford, M. L., Banta, J. A., Katari, M. S., Hulsmans, J., Chen, L., Ristova, D., et al. (2013). Plasticity regulators modulate specific root traits in discrete nitrogen environments. PLoS Genet. 9:e1003760. doi: 10.1371/journal.pgen.1003760

Guo, F. Q., Young, J., and Crawford, N. M. (2003). The nitrate transporter AtNRT1.1 (CHL1) functions in stomatal opening and contributes to drought susceptibility in Arabidopsis. Plant Cell 15, 107-117. doi: 10.1105/tpc.006312

\section{AUTHOR CONTRIBUTIONS}

BL conceived and designed the experiments, provided financial support, and helped perform the analysis with constructive discussions. PD performed the experiments with assistance from $\mathrm{BY}, \mathrm{YC}, \mathrm{RH}, \mathrm{JJ}$, and $\mathrm{XH}$. PD analyzed the data and wrote the manuscript. JX provided materials and laboratory apparatus. All the authors contributed to the article and approved the submitted version.

\section{FUNDING}

This work was supported by the National Natural Science Foundation of China (31901964), the Natural Science Foundation of Hebei (C2021204158), the Introduced Talents Project of Hebei Agricultural University (YJ201904), and the China Agriculture Research System of MOF and MARA (CARS-27).

Guo, J. H., Liu, X. J., Zhang, Y., Shen, J. L., Han, W. X., Zhang, W. F., et al. (2010). Significant acidification in major Chinese croplands. Science 327, 1008-1010. doi: $10.1126 /$ science. 1182570

Hattori, A., Migitaka, H., Iigo, M., Itoh, M., Yamamoto, K., Ohtani-Kaneko, R., et al. (1995). Identification of melatonin in plants and its effects on plasma melatonin levels and binding to melatonin receptors in vertebrates. Biochem. Mol. Biol. Int. 35, 627-634.

Högberg, P., Granström, A., Johansson, T., Lundmark-Thelin, A., and Näsholm, T. (1986). Plant nitrate reductase activity as an indicator of availability of nitrate in forest soils. Can. J. Forest Res. 16, 1165-1169. doi: 10.1139/x86-207

Huang, L. L., Li, M. J., Zhou, K., Sun, T. T., Hu, L. Y., Li, C. Y., et al. (2018). Uptake and metabolism of ammonium and nitrate in response to drought stress in Malus prunifolia. Plant Physiol. Biochem. 127, 185-193. doi: 10.1016/j.plaphy. 2018.03.031

Jia, Z., Giehl, R. F. H., Meyer, R. C., Altmann, T., and von Wiren, N. (2019). Natural variation of BSK3 tunes brassinosteroid signaling to regulate root foraging under low nitrogen. Nat. Commun. 10, 611-627. doi: 10.1038/s41467-01910331-9

Kanwar, M. K., Yu, J., and Zhou, J. (2018). Phytomelatonin: recent advances and future prospects. J. Pineal Res. 65:e12526. doi: 10.1111/jpi.12526

Kiba, T., Feria-Bourrellier, A. B., Lafouge, F., Lezhneva, L., Boutet-Mercey, S., Orsel, M., et al. (2012). The Arabidopsis nitrate transporter NRT2.4 plays a double role in roots and shoots of nitrogen-starved plants. Plant Cell 24, 245-258. doi: 10.1105/tpc.111.092221

Kimura, M. (1968). Fluorescence histochemical study on serotonin and catecholamine in some plants. Jpn. J. Pharmacol. 18, 162-168. doi: 10.1254/jjp. 18.162

Krouk, G., Lacombe, B., Bielach, A., Perrine-Walker, F., Malinska, K., Mounier, E., et al. (2010). Nitrate-regulated auxin transport by NRT1.1 defines a mechanism for nutrient sensing in plants. Dev. Cell. 18, 927-937. doi: 10.1016/j.devcel.2010. 05.008

Kulma, A., and Szopa, J. (2006). Catecholamines are active compounds in plants. Plant Sci. 172, 433-440. doi: 10.1016/j.plantsci.2006.10.013

Lezhneva, L., Kiba, T., Feria-Bourrellier, A. B., Lafouge, F., Boutet-Mercey, S., Zoufan, P., et al. (2014). The Arabidopsis nitrate transporter NRT2.5 plays a role in nitrate acquisition and remobilization in nitrogen-starved plants. Plant J. 80, 230-241. doi: 10.1111/tpj.12626

Li, C., Liang, B. W., Chang, C., Wei, Z. W., Zhou, S. S., and Ma, F. W. (2016). Exogenous melatonin improved potassium content in Malus under different stress conditions. J. Pineal Res. 61, 218-229. doi: 10.1111/jpi.12342

Li, C., Sun, X. K., Chang, C., Jia, D. F., Wei, Z. W., Li, C. Y., et al. (2015). Dopamine alleviates salt-induced stress in Malus hupehensis. Physiol. Plantarum 153, 584-602. doi: 10.1111/ppl.12264 
Liang, B. W., Gao, T. T., Zhao, Q., Ma, C. Q., Chen, Q., Wei, Z. W., et al. (2018a). Effects of exogenous dopamine on the uptake, transport, and resorption of apple ionome under moderate drought. Front. Plant Sci. 9:755. doi: 10.3389/fpls.2018. 00755

Liang, B. W., Ma, C. Q., Zhang, Z. J., Wei, Z. W., Gao, T. T., Zhao, Q., et al. (2018b). Long-term exogenous application of melatonin improves nutrient uptake fluxes in apple plants under moderate drought stress. Environ. Exp. Bot. 155, 650-661.

Liang, B. W., Li, C. Y., Ma, C. Q., Wei, Z. W., Wang, Q., Huang, D., et al. (2017). Dopamine alleviates nutrient deficiency-induced stress in Malus hupehensis. Plant Physiol. Biochem. 119, 346-359.

Liang, C. Z., Zheng, G. Y., Li, W. Z., Wang, Y. Q., Hu, B., Wang, H. R., et al. (2015). Melatonin delays leaf senescence and enhances salt stress tolerance in rice. J. Pineal Res. 59, 91-101.

Liang, D., Ni, Z. Y., Xia, H., Xie, Y., Lv, X. L., Wang, J., et al. (2019). Exogenous melatonin promotes biomass accumulation and photosynthesis of kiwifruit seedlings under drought stress. Sci. Hortic.-Amsterdam 246, 34-43.

Lin, C. C., and Kao, C. H. (1996). Disturbed ammonium assimilation is associated with growth inhibition of roots in rice seedlings caused by $\mathrm{NaCl}$. Plant Growth Regul. 18, 233-238.

Liu, Q. W., Gao, T. T., Liu, W. X., Liu, Y. S., Zhao, Y. J., Liu, Y. R., et al. (2020). Functions of dopamine in plants: a review. Plant Signal Behav. 15:1827782. doi: 10.1080/15592324.2020.1827782

Liu, X. M., Gao, T. T., Zhang, Z. J., Tan, K. X., Jin, Y. B., Zhao, Y. J., et al. (2020). The mitigation effects of exogenous dopamine on low nitrogen stress in Malus hupehensis. J. Integr. Agr. 19, 2709-2724. doi: 10.1016/s2095-3119(20)63344-5

Liu, Y. Q., Wang, H. R., Jiang, Z. M., Wang, W., Xu, R. N., Wang, Q. H., et al. (2021). Genomic basis of geographical adaptation to soil nitrogen in rice. Nature 590, 600-605. doi: 10.1038/s41586-020-03091-w

Maathuis, F. J. (2009). Physiological functions of mineral macronutrients. Curr. Opin. Plant Biol. 12, 250-258. doi: 10.1016/j.pbi.2009.04.003

Miller, A. J., and Cramer, M. D. (2005). Root nitrogen acquisition and assimilation. Plant Soil 274, 1-36.

Ogawa, K., Shiraishi, N., Ida, S., Nakagawa, H., and Komamine, A. (1999). Effects of glutamine on the induction of nitrate reductase and nitrite reductase in cultured spinach cells. J. Plant Physiol. 154, 46-50. doi: 10.1016/s0176-1617(99)80316-2

Qi, J. G., Sun, S. M., Yang, L., Li, M. J., Ma, F. W., and Zou, Y. J. (2019). Potassium uptake and transport in apple roots under drought stress. Hortic. Plant J. 5, 10-16. doi: 10.1016/j.hpj.2018.10.001

Rezaei, M., Naghavi, M. R., Hoseinzade, A. H., and Abbasi, A. (2016). Developmental accumulation of thebaine and some gene transcripts in different organs of Papaver bracteatum. Ind. Crop Prod. 80, 262-268.

Sánchez-Rodríguez, E., Rubio-Wilhelmi, M. D., Cervilla, L. M., Blasco, B., Rios, J. J., Leyva, R., et al. (2010). Study of the ionome and uptake fluxes in cherry tomato plants under moderate water stress conditions. Plant Soil 335, 339-347. doi: 10.1007/s11104-010-0422-2

Sharma, A., Wang, J. F., Xu, D. B., Tao, S. C., Chong, S. L., Yan, D. L., et al. (2020). Melatonin regulates the functional components of photosynthesis, antioxidant system, gene expression, and metabolic pathways to induce drought resistance in grafted Carya cathayensis plants. Sci. Total Environ. 713:136675. doi: 10.1016/ j.scitotenv.2020.136675

Shiva, B., Alan, K. M., Elisa, C. P., and Dijkstra, F. (2016). Dual-labeling with ${ }^{15} \mathrm{~N}$ and $\mathrm{H}_{2}^{18} \mathrm{O}$ to investigate water and $\mathrm{N}$ uptake of wheat under different water regimes. Plant Soil 408, 429-441.

Su, H., Wang, T., Ju, C. F., Deng, J. P., Zhang, T. Q., Li, M. J., et al. (2020). Abscisic acid signaling negatively regulates nitrate uptake via phosphorylation of NRT1.1 by SnRK2s in Arabidopsis. J. Integr. Plant Biol. 63, 597-610. doi: 10.1111/jipb.13057

Sun, Q. Q., Zhang, N., Wang, J. F., Zhang, H. J., Li, D. B., Shi, J., et al. (2015). Melatonin promotes ripening and improves quality of tomato fruit during postharvest life. J. Exp. Bot. 66, 657-668. doi: 10.1093/jxb/eru332

Tsay, Y. F., Schroeder, J. I., Feldmann, K. A., and Crawford, N. M. (1993). The herbicide sensitivity gene CHL1 of Arabidopsis encodes a nitrate-inducible nitrate transporter. Cell 72, 705-713. doi: 10.1016/0092-8674(93)90399-b

Verelst, W., and Asard, H. (2004). Analysis of an Arabidopsis thaliana protein family, structurally related to cytochromes b561 and potentially involved in catecholamine biochemistry in plants. J. Plant Physiol. 161, 175-181. doi: 10. 1078/0176-1617-01064

Viktor, A., and Cramer, M. D. (2005). The influence of root assimilated inorganic carbon on nitrogen acquisition/assimilation and carbon partitioning. New Phytol. 165, 157-169. doi: 10.1111/j.1469-8137.2004.01204.x

Wang, L., Feng, C., Zheng, X. D., Guo, Y., Zhou, F. F., Shan, D. Q., et al. (2017). Plant mitochondria synthesize melatonin and enhance the tolerance of plants to drought stress. J. Pineal Res. 63:e12429. doi: 10.1111/jpi.12429

Wang, L., Zhou, Q. X., Ding, L. L., and Sun, Y. B. (2008). Effect of cadmium toxicity on nitrogen metabolism in leaves of Solanum nigrum L. as a newly found cadmium hyperaccumulator. J. Hazard. Mater. 154, 818-825. doi: 10. 1016/j.jhazmat.2007.10.097

Wang, Q. B., An, B., Wei, Y. X., Reiter, R. J., Shi, H. T., Luo, H. L., et al. (2016). Melatonin regulates root meristem by repressing auxin synthesis and polar auxin transport in Arabidopsis. Front. Plant Sci. 7:1882. doi: 10.3389/fpls.2016. 01882

Wang, S., Che, T., Levit, A., Shoichet, B. K., Wacker, D., and Roth, B. L. (2018). Structure of the D2 dopamine receptor bound to the atypical antipsychotic drug risperidone. Nature 555, 269-273. doi: 10.1038/nature25758

Wang, Y. Y., Cheng, Y. H., Chen, K. E., and Tsay, Y. F. (2018). Nitrate transport, signaling, and use efficiency. Annu. Rev. Plant Biol. 69, 85-122. doi: 10.1146/ annurev-arplant-042817-040056

Wei, J., Li, D. X., Zhang, J. R., Shan, C., Rengel, Z., Song, Z. B., et al. (2018). Phytomelatonin receptor PMTR1-mediated signaling regulates stomatal closure in Arabidopsis thaliana. J. Pineal Res. 65:e12500. doi: 10.1111/jpi.12500

Xu, G. H., Fan, X. R., and Miller, A. J. (2012). Plant nitrogen assimilation and use efficiency. Annu. Rev. Plant Biol. 63, 153-182. doi: 10.1146/annurev-arplant042811- 105532

Ying, L., and Nicolaus, V. W. (2017). Ammonium as a signal for physiological and morphological responses in plants. J. Exp. Bot. 68, 2581-2592. doi: 10.1093/jxb/ erx086

Zhang, H., and Forde, B. G. (1998). An Arabidopsis MADS box gene that controls nutrient-induced changes in root architecture. Science 279, 407-409. doi: 10. 1126/science.279.5349.407

Zhang, H. J., Zhang, N., Yang, R. C., Wang, L., Sun, Q. Q., Li, D. B., et al. (2014). Melatonin promotes seed germination under high salinity by regulating antioxidant systems, ABA and GA(4) interaction in cucumber (Cucumis sativus L.). J. Pineal Res. 57, 269-279. doi: 10.1111/jpi.12167

Zhang, R. M., Sun, Y. K., Liu, Z. Y., Jin, W., and Sun, Y. (2017). Effects of melatonin on seedling growth, mineral nutrition, and nitrogen metabolism in cucumber under nitrate stress. J. Pineal Res. 62:e12403. doi: 10.1111/jpi.12403

Zhang, X., Cui, Y. N., Yu, M., Su, B. D., Gong, W., Baluska, F., et al. (2019). Phosphorylation-mediated dynamics of nitrate transceptor NRT1.1 regulate auxin flux and nitrate signaling in lateral root growth. Plant Physiol. 181, 480-498. doi: 10.1104/pp.19.00346

Zhang, X., Davidson, E. A., Mauzerall, D. L., Searchinger, T. D., Dumas, P., and Shen, Y. (2015). Managing nitrogen for sustainable development. Nature 528, 51-59. doi: 10.1038/nature 15743

Conflict of Interest: The authors declare that the research was conducted in the absence of any commercial or financial relationships that could be construed as a potential conflict of interest.

Publisher's Note: All claims expressed in this article are solely those of the authors and do not necessarily represent those of their affiliated organizations, or those of the publisher, the editors and the reviewers. Any product that may be evaluated in this article, or claim that may be made by its manufacturer, is not guaranteed or endorsed by the publisher.

Copyright (c) $2022 \mathrm{Du}$, Yin, Cao, Han, Ji, He, Liang and Xu. This is an open-access article distributed under the terms of the Creative Commons Attribution License (CC BY). The use, distribution or reproduction in other forums is permitted, provided the original author(s) and the copyright owner(s) are credited and that the original publication in this journal is cited, in accordance with accepted academic practice. No use, distribution or reproduction is permitted which does not comply with these terms. 